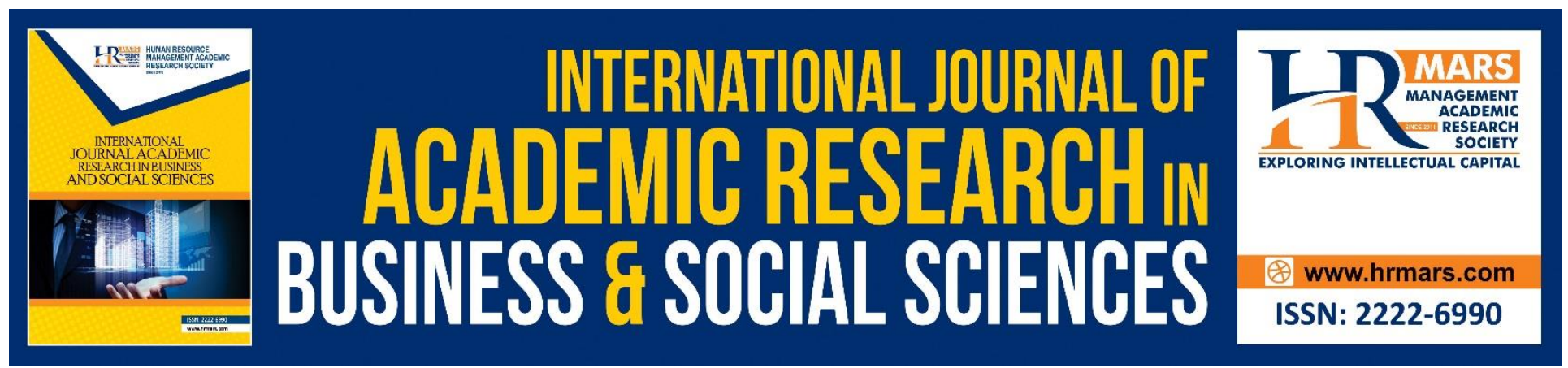

\title{
Identifying and Prioritizing Research Gaps in Studies related to Total Quality Management on Competitive Advantage in Malaysian Hotel Industries
}

Kit Yeng Sin, Muhammad Shahar Jusoh

To Link this Article: http://dx.doi.org/10.6007/IJARBSS/v9-i5/5875

DOI: $10.6007 /$ IJARBSS/v9-i5/5875

Received: 22 March 2019, Revised: 22 April 2019, Accepted: 1 May 2019

Published Online: 21 May 2019

In-Text Citation: (Sin \& Jusoh, 2019)

To Cite this Article: Sin, K. Y., \& Jusoh, M. S. (2019). Identifying and Prioritizing Research Gaps in Studies related to Total Quality Management on Competitive Advantage in Malaysian Hotel Industries. International Journal of Academic Research Business and Social Sciences, 9(5), 335-349.

Copyright: (C) 2019 The Author(s)

Published by Human Resource Management Academic Research Society (www.hrmars.com)

This article is published under the Creative Commons Attribution (CC BY 4.0) license. Anyone may reproduce, distribute, translate and create derivative works of this article (for both commercial and non-commercial purposes), subject to full attribution to the original publication and authors. The full terms of this license may be seen

at: http://creativecommons.org/licences/by/4.0/legalcode

Vol. 9, No. 5, 2019, Pg. 335 - 349

http://hrmars.com/index.php/pages/detail/IJARBSS

JOURNAL HOMEPAGE

Full Terms \& Conditions of access and use can be found at http://hrmars.com/index.php/pages/detail/publication-ethics 


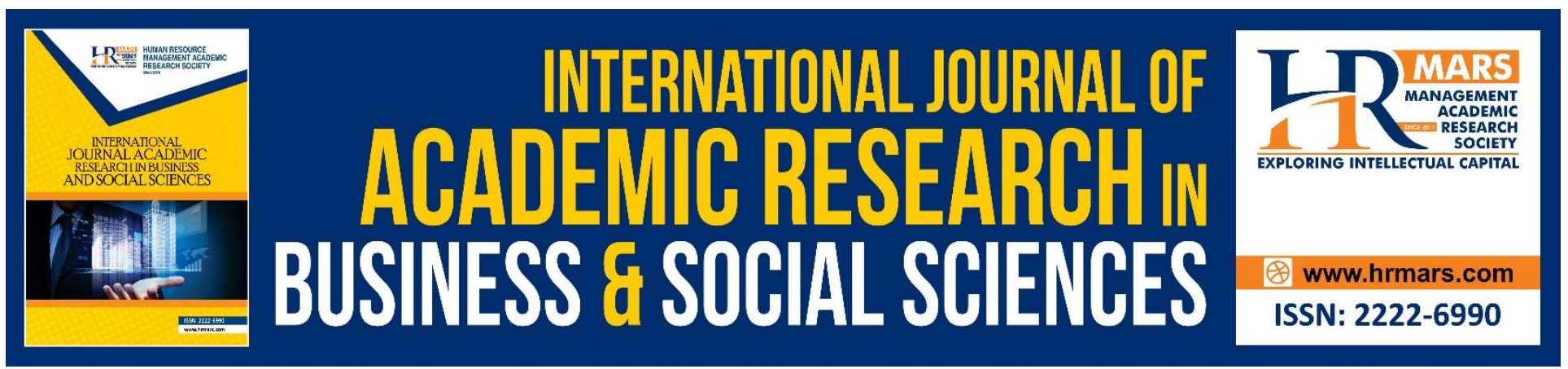

\title{
Identifying and Prioritizing Research Gaps in Studies related to Total Quality Management on Competitive Advantage in Malaysian Hotel Industries
}

\author{
Kit Yeng $\operatorname{Sin}^{1}$, Muhammad Shahar Jusoh² \\ ${ }^{1}$ Universiti Malaysia Sarawak, Faculty of Economics and Business, 94300 Sarawak, Malaysia. \\ ${ }^{2}$ University Malaysia Perlis (UniMAP), School of Business Innovation \& Technopreneurship, 01000 \\ Kangar, Malaysia.
}

\begin{abstract}
Determining research gaps is a cardinal goal in literature review. While it has been diffusely conceded that literature reviews should determine research gaps, no methodological orientation is available on how to pinpoint research gaps amidst review of literature or to assure rigor and replicability. Hence, this study addresses this gap and puts forward a simple prototype that should assist scholars in this endeavour without suppressing creativity. Based on the study outcomes, a technique has been generated to identify research gaps, so as to enable scholars to conduct a more rigorous, effective, and efficient literature reviews henceforth.
\end{abstract}

Keywords: Literature review, Research gap, Total Quality Management (TQM), Competitive advantage (CA), Hotel industry

\section{Introduction}

Tourism has been the second largest foreign exchange generator in Malaysia after the manufacturing sector, accounting for $5.7 \%$ and $14.9 \%$ of direct and indirect contribution, respectively, to the Gross Domestic Product (GDP) in year 2014, and this figure has been expected to escalate by $4.5 \%$ per annum to Malaysia Ringgit (MYR) 262.2 billion by year 2025 (Hospitality Valuation Services (HVS), October 2015). Ranked within the top 10 tourism destination, undeniably, Malaysia has flourished within the tourism sector (Malaysia Investment Development Authority, 2015) and income generated was forecasted to rise by 4.6\% per annum for 2013 until 2022, to a whopping MYR 90.7Bn in 2022 (World Travel and Tourism Council, 2012). The tourism industry has opened up new opportunities and benefited Malaysians by bringing in RM19.4 billion of investments and contributing to 1.77 million jobs (13\% of total employment) in 2014 alone since the inception of National Transformation Programme (NTP) (The Sun Daily, October 2015). No doubt, the strong and significant rise of tourism development since the past few decades is one of the most remarkable social, economic, and cultural 
phenomena in Malaysia. Nevertheless, in this age of global competitive setting, substitute products, services, and destinations have become vast and this has led to the emergence of quality as not only an issue to be addressed, but also as a competitive opportunity within the tourism domain (Katerina, Ida, \& Jakub, 2013). Since quality contributes to greater market share and return on investment (Hassan, Rushami \& Abdullah, 2013), lowers manufacturing costs, enhances productivity (Khanam \& Siddiqui \& Talib, 2013), and improves strategic performance (Talabi, 2015). At present dynamic and competitive business scenario, attaining quality is an integral aspect in every organization (Haider, Shoaib \& Kanwal, 2015). It is integral for Malaysia to improve the quality of its services and products, particularly within its hospitality sphere not only because Malaysia is a popular destination for meetings, incentives, conferences, and exhibitions (MICE); but also to remain competitive with its contenders, such as Singapore, Thailand, Korea, and Japan (HVS, October 2015). Apart from having workforce with multiple cultures, languages, ethnicities, and beliefs; hotels in Malaysia are sought to satisfy customer demands particularly in the advent of competitive market, mushrooming of new tourist destinations, manpower demand as a consequence of globalization, as well as evolution in demographic, economic, and technological aspects, which pose unimaginable challenges to attract customers (Horng, Liu, Chou, Yin \& Tsai, 2013). Therefore, besides creative marketing, implementation and effective practices of quality management appear to be significant factors that dictate prosperity and flourishing amongst Malaysian hoteliers (Mihail \& Kloutsiniotis, 2016).

The vast implementation of Total Quality Management (TQM) has exerted a great impact upon worldwide hotel domain, which has been reckoned as an imminent factor that distinguishes service products from building competitive advantage (CA) (Haider et al., 2015). The TQM serves as an instrument that contributes to high productivity offered by the workforce and to stabilise high work quality at the organization level. In precise, implementation and effective practice of TQM assures a company with an exceptional image (Abbas, Hunjra, Azam, ljaz \& Zahid, 2014).

The hotel industry to date seems to be given a range of TQM options (Cemal, Oznur, Songul \& Busra, 2012; Arawati \& Zafara, 2011). Due to incomprehensive knowledge pertaining to TQM within the hotelier context, a pressing need exists to aid the Malaysian hotel domain in assessing TQM practices and in selecting the most suitable option to ensure ideal management practice at the organization level (Abbas, Ahmad, Mahdi \& Mansooreh, 2015). This is bound to satisfy the needs of employees, boost their work performance (Gholamreza, Mehran \& Mohammad, 2010), and minimize unnecessary expenditure (Abbas et al., 2014).

Despite the significance of TQM implementation in organizations, not much information is available on how hoteliers assess and choose the appropriate TQM practices for their hotel management (Arasli, 2012). Additionally, only a handful of TQM models are found in the literature to aid hoteliers determine and assess TQM practices that best fit the Malaysian hotel industry, in tandem of the Ministry of Tourism and Culture in achieving its National Key Economic Area (NKEA), and of the nation in becoming one that is high income by 2020. 


\section{Literature Review \\ Definition of the Study Concept(s)/ Construct(s)}

The term 'concept' refers to the building blocks in social studies and the fundamental units in developing a theory (Buchbinder, Batterham, Elsworth, Dionne, Irvin \& Osborne, 2011). The absence of well-defined concepts that reflect research terms can lead to incoherent theory (Conrad, Ridings, Iris, Fairman, Anetzberger \& Rosen, 2011). For instance, in the event of unestablished concepts, one would not be able to related one concept to another, hence failure in devising a valid measure and in constructing the rationale for a theory (DeVellis, 2011). Jordan, Buchbinder, Briggs, Elsworth, Busija, Batterham, and Osborne (2013) asserted the following: "... confusion in research concept meaning can destroy the value of a research without the researcher even knowing it. If words have varied meanings to the parties involved, then they do not communicate on the same wavelength. Definition refers to one effective way to reduce this danger".

In the attempt of assessing the correlation between CA and TQM, this study has outlined the definitions of CA and TQM and operationalised them prior to empirical testing.

Extensive literature review was performed to seek the essence of a good definition. In line with this, Routio (2009) listed the four criteria that every definition should satisfy, which are: (1) Validity a definition should match only its concept and only measure what it is supposed to measure, nothing beyond that; (2) Reliability - the outcomes should always be the same despite repetitive measurement; (3) A definition should not be a vicious circle - e.g., quality management differs from management of quality; and lastly, (4) Absence of obscure or figurative expression. This study had employed the listed four criteria in order to assess the available TQM and CA definitions, as discussed in the following:

\section{TQM}

TQM is in the cutting-edge of quality management in most industries (Singh et al., 2015). In fact, TQM refers to philosophy and guiding justifications that are meant to enhance an organization. One of the approaches that seem to provide the solution to the challenges could be the management philosophy of TQM (Masejane, 2012). With the potential of reinforcing competitiveness, strengthening organizational efficacy, and satisfying customer needs, TQM looks into system efficacy, such as customer satisfaction, production line, planning, designing, techniques adopted, and quality instrument (Khanam, Siddiqui \& Talib, 2015). With the expansion of global market competition, innumerable organisations constantly view the application of TQM approaches as a means to promote and to sustain organizational renaissance and manifestation (Baird, Hu \& Reeve, 2011).

Literature pertaining to quality management presents a wide spectrum of definitions for TQM (Al-Dhaafri, Yusoff \& Al-swidi, 2013). Boateng-Okrah and Fening (2012) defined TQM as an approach that demands participation from all levels to constantly improve the quality of delivered goods/services. Junior, Lucato, Vanalle and Jagoda (2014) defined TQM as a philosophy of management that aids organisations yield efficiency and quality of goods/services by improving the quality of products/services and by increasing satisfaction amongst customers. Calvo-Mora, Picón, Ruiz and Cauzo (2014) described TQM as a set of techniques and action plans employed to eliminate variation from a production process or service-delivery system so as to improve reliability, efficiency, and quality. 
INTERNATIONAL JOURNAL OF ACADEMIC RESEARCH IN BUSINESS AND SOCIAL SCIENCES Vol. 9, No. 5, May, 2019, E-ISSN: 2222-6990 ㄷ 2019 HRMARS

Meanwhile, Hung, Lien, Yang, Wu and Kuo (2011) disputed that customer needs and processes are complemented; hence, fabricating better planning, better design, better external and internal focus, preserving strong area, and reinforcing weak processes can be attained by TQM. Jenkins and Delbridge (2013) asserted that TQM is a merged philosophy of management for constant improvement of product and process quality to ensure customer satisfaction. Yusoff, Aichouni, Badawi and Boujelbene (2016) claimed that TQM based on the participation of all organizational levels in enhancing processes, products, services, and the culture in which they work can be defined as a management approach aimed for long-term success by focusing on customer satisfaction. The primary intent of TQM is continuous improvement in operational activities to achieve growth in production and sales, as well as to gain higher level of satisfaction amidst customers and stakeholders (Tasleem, Khan \& Masood, 2015).

Based on the four criteria listed by Routio (2009), a valid TQM definition for the hotel context should embed the meaning of conformance to internal provisions (Sadikoglu \& Zehir, 2010), as demanded by customers and stakeholders (Huang et al., 2013; Fotopoulos \& Psomas, 2010). Besides, if one intends to measure the definition in other contexts, such as service and manufacturing industries, the outcomes must be similar (Valmohammadi, 2011), or in precise, reliable based on the criteria listed by Routio (2009). As such, this study proposes the following new TQM definition, which has been drawn from Tasleem et al., (2015) and Yusoff et al., (2016) in adherence to Routio's (2009) criteria.

TQM is a management-based approach with participation of all members of an organisation in improving processes, products, services, and culture in order to achieve higher level of satisfaction of customers and other associated stakeholders.

\section{Competitive Advantage (CA)}

Despite the vast CA determinants within the domain of strategic management (Andersén, 2011), a vivid definition of CA is unavailable (Sigalas \& Economou, 2013).

The definitions of CA found in the literature appeared to be invalid, as they did not match the concept based on Routio's (2009) criteria (Rossem \& Veen, 2011). Several defined CA based on the available sources (see Barney, 1991; Collis \& Montgomery, 1995; Wiggins \& Ruefli, 2002; Porter, 1985), while some omitted the notion of contenders in defining CA (see Mahlendorf, Rehring, Schäffer \& Wyszomirski, 2012), and others included ambiguous figurative expression (see Thompson \& Martin, 2006).

In precise, some CA definitions failed to meet the criteria listed by Routio (2009) since CA was mostly defined based on sources, while disregarding the construct of CA itself (Liou \& Gao, 2011). The potential CA sources can be identified within an organization, such as its activities in association with producing, designing, delivering, marketing, as well as supporting the sales product/services (Sigalas, Pekka-Economou \& Georgopoulos, 2013). Thus, the definition of CA based on sources becomes invalid, as the very concept of CA is undermined (Sigalas et al., 2013).

Similarly, some CA definitions omitted the notion of competitors, which is an essential element in CA. For instance, Porter (1985:3) claimed that CA emerges based on a value that an organization can generate for the customers, hence exceeding firm cost in the process of generating the value (Karfestani, Shomami \& Hasanvand, 2013). 
INTERNATIONAL JOURNAL OF ACADEMIC RESEARCH IN BUSINESS AND SOCIAL SCIENCES Vol. 9, No. 5, May, 2019, E-ISSN: 2222-6990 @ 2019 HRMARS

Figurative expression is abhorred in the criteria listed by Routio (2009), mainly because it invites ambiguity that disrupts the real meaning of the definition. For instance, when CA is defined as a unique position that an organization achieves when compared to contenders, it invites vagueness in the notion 'unique position' and in its measurement (Casanueva et al., 2015).

In adherence to Routio's (2009) criteria, Marcus (2005) and Mooney (2007) proposed measurable (reliable) definition for CA. They defined CA as 'achieving above average performance, when compared to the competitors within the industry'. Additionally, varying performance dimensions were employed, for example, financial returns indicators (e.g., ROI, ROA, ROE) (Gallo, 2016), customer satisfaction (Jacobson \& Mizik, 2013), profits (Coleman, de Chernatony \& Christodoulides, 2015), market share (Feng, Morgan \& Rego, 2015), and employee productivity (Dunes \& Pras, 2013).

The CA definition as 'above average performance as compared to firm competitors', can be applied in this present study due to its validity (a definition that matches the concept, which dismisses CA sources and includes competitors), clarity (absence of figurative expression), and reliability (consistent measured outcomes). This particular definition reflects two key conditions for CA: (1) existence of contenders, and (2) achieving above-average performance. Therefore, the definition of CA in this study has been adopted from that proposed by Newbert (2008) and further improved by Sigalas et al., (2013, p. 335), primarily because this definition satisfies the twoabovementioned conditions for $\mathrm{CA}$ :

$C A$ is the above industry average manifested exploitation of market opportunities and neutralisation of competitive threats.

\section{Studies of TQM}

A substantial number of researches have pointed out the positive impact of TQM upon business performance (Zwain et al., 2017; Lee et al., 2014). One can conclude that organizations with effective TQM implementation can gain several internal benefits, such as quality improvement, productivity enhancement, and realization of better operating income (Chiarini et al., 2016).

Outcomes of TQM implementation have displayed success in improving an organization's physical performance in terms of financial achievement (Herzallah et al., 2014; Wayhan et al., 2013), quality performance (Talib et al., 2013b), organizational performance (Costantini et al., 2015; Herzallah et al., 2014; Mehmood et al., 2014; Gambi et al., 2013; Wayhan et al., 2013; Valmohammadi, 2011; Fotopoulos et al., 2010), operational performance (Sadikoglu et al., 2014; Irfan et al., 2012), product innovation performance (Leavengood et al., 2012), CA (Phan et al., 2011), as well as in terms of those invisible forms, such as customer orientation (Ang et al., 2011), market orientation (Lam et al., 2012), and service quality (Al-Hawary et al., 2013).

Surveys conducted in light of TQM portray that the frequency of research publications within the service domain has escalated substantially and covers a wide spectrum of service industries, for example, information and communication technology (ICT) (Santouridis \& Trivellas, 2010; Mahadeo \& Durbarry, 2008), banking (Sit et al., 2011; Ho \& Lin, 2010), healthcare (Irfan et al., 2012; Hazilah, 2009), education (Ali et al., 2010; Mehralizadeh \& Safaeemoghadddam, 2010), and other service firms (Lee at al., 2014; Al-Hawary et al., 2013; Talib et al., 2013b; Lam et al., 2012; Leavengood et al., 2012; Ang et al., 2011). 
Therefore, a pressing need exists to determine and to assess TQM practices, as well as their implementation within the service industry, especially to boost business growth and performance (Bon \& Mustafa, 2013; Karani \& Bichanga, 2012). Nevertheless, studies that have probed into identifying TQM practices within the service sector, particularly hospitality industry, seem to be at a nascent stage, which had motivated the authors of this study to determine the TQM key practices suitable and applicable for the hospitality industry in Malaysia.

\section{Studies related to TQM in the Hospitality Industry}

In summary, the existing studies regarding quality management within hospitality settings mainly focused on the quantitative approach by determining the correlations between service quality and customer satisfaction (Sushila, et al., 2014), service quality and hotel performance (Abbas et al., 2015), quality management practices and business results (Carlos et al., 2014; Wang et al., 2012; Juan et al., 2010), quality management practices and innovation performance (Zeng, Phan \& Matsui, 2015), quality management practices and hotel labor productivity (Carlos et al., 2014) as well as quality management practices and CA (Jose, et al., 2015). Several researches determined solely one of the TQM dimensions, which is leadership towards employee creativity (Wang et al., 2014), hotel performance (Wu et al., 2015), and negative work-home interference (Debbie et al., 2014).

Among all these hospitality researches aforementioned, most of them were carried out in developed and tourism leading countries, such as Spain (Jose, et al., 2015; Carlos, et al., 2014; Juan et al., 2010), China (Wang et al., 2012), Taiwan (Wu et al., 2015; Wang et al., 2014; Chen, Hsu \& Tzeng, 2011), and Jordan (Abbas, 2015), while scarce in developing nations, such as Malaysia (Sushila et al., 2014; Mensah, Copuroglu, \& Fening, 2012).

\section{Studies of TQM \& CA in the Hotel Industry}

As the majority general studies focused on quality management, some of these analyses showed that quality management has a positive impact on CA. This indicates that quality management may improve the internal functions of a hotel, which leads to enhanced productivity in workers and facilities, improved efficiency, and reduction in errors and waste upon services provision. In turn, it may also exert a positive impact on customer satisfaction, which may increase sales and market share, reinforce guest loyalty, attract new guests, increase tourist satisfaction, and improve the image of the hotel. In this way, quality management may increase quality performance, and in turn, may improve the CA of hotel establishments. Nevertheless, the study of quality management in relation to $C A$ is limited within the hotel industry, thus motivated the authors to conduct the study in line with the problem stated above.

\section{Studies of TQM Evaluation in the Hotel Industry}

Prior studies indicated that most articles have discussed the assessment and evaluation in terms of hotel service quality or other criteria using quantitative method (Tseng et al., 2015; Chen et al., 2011), while only a handful has assessed quality management, especially TQM, in hotel settings using qualitative or mixed method approach (Abbas et al., 2015). The previously mentioned articles discussed the evaluation and assessment processes using cases of tourism in leading and developed countries, such as Spain (Juan et al., 2010), Taiwan (Tseng et al., 2015), and Jordan (Abbas et al., 
2015). To date, many developing nations have begun adopting TQM or other national excellence model based on the historical excel-experience of the developed countries. Nonetheless, those developing nations have different characteristics and cultural values, when compared to developed countries; thus signifying the urgent need to examine TQM evaluation and assessment. This is mainly because the demand for quality has escalated since the past decades as a result of changing economy and competitive environment. Therefore, adopting the mixed method approach as a research method can be a future path for this study arena, in order to elicit clear and well-rounded answers on the degree and extension of quality management practices within Malaysia's hotel industry ( $\mathrm{Wu}$ \& Chen, 2015; Carlos et al., 2014).

\section{Result and Discussions}

Identification of Gaps in the Literature

Table 1: Overview of TQM and related studies from 2010-2018

\begin{tabular}{|c|c|c|c|c|c|c|}
\hline Year & $\begin{array}{c}\text { TQM } \\
\text { review }\end{array}$ & $\begin{array}{c}\text { TQM \& } \\
\text { hospitality } \\
\text { review }\end{array}$ & \begin{tabular}{|c|} 
TQM \& hotel \\
industry \\
review
\end{tabular} & $\begin{array}{c}\text { TQM \& } \\
\text { Competitive } \\
\text { Advantage } \\
\text { (CA) in hotel } \\
\text { industry } \\
\text { review }\end{array}$ & $\begin{array}{l}\text { Assessing } \\
\text { and } \\
\text { evaluating } \\
\text { TQM \& CA } \\
\text { in hotel } \\
\text { industry }\end{array}$ & $\begin{array}{l}\text { Assessing } \\
\text { and } \\
\text { evaluating } \\
\text { TQM \& CA in } \\
\text { hotel } \\
\text { industry } \\
\text { using Mixed } \\
\text { Method }\end{array}$ \\
\hline 2010 & 18 & 2 & 1 & - & - & - \\
\hline 2011 & 10 & 2 & 1 & - & - & - \\
\hline 2012 & 12 & 1 & 1 & - & - & - \\
\hline 2013 & 16 & - & - & - & - & - \\
\hline 2014 & 13 & 1 & 1 & - & - & - \\
\hline 2015 & 17 & 1 & 1 & - & - & - \\
\hline 2016 & 15 & 4 & 2 & - & - & - \\
\hline 2017 & 11 & 6 & 4 & 1 & 1 & - \\
\hline 2018/March & 8 & - & - & - & - & - \\
\hline Total & 120 & 17 & 11 & 1 & 1 & 0 \\
\hline
\end{tabular}

Source: Compiled by the Authors

Table 1 shows that a total of 120 papers established from 2010 to 2018 March extracted from online databases, such as ScienceDirect, Springer, Emerald, Wiley, ProQuest, and Taylor \& Francis, had been reviewed in this study.

Among those reviewed, most of them were carried out in manufacturing industries (Changiz et al., 2015; Cemal et al., 2012; Philipp et al., 2012; Arawati et al., 2011), industrial companies (Richard et al., 2011), e-government (Huai, 2012), banking industry (Snezana, 2015; Zahra, Alireza \& Mohammad, 2014), food companies (Evangelos, Fotis \& Dimitrios, 2014; Hayati \& Khairul, 2014), and 
INTERNATIONAL JOURNAL OF ACADEMIC RESEARCH IN BUSINESS AND SOCIAL SCIENCES Vol. 9, No. 5, May, 2019, E-ISSN: 2222-6990 ㄷ 2019 HRMARS

pharmaceutical firms (Gholamhossein, Jamal, Hamid \& Sajjad, 2016), while scarcely within the hospitality domain, which accounted for $14.17 \%$ from the total 120 papers.

Similarly, reviews regarding TQM and hotel industry are limited, as most of them were keen in determining the correlation between TQM and hotel performance (Wang et al., 2012), TQM and CA (Jose et al., 2015), hard and soft TQM towards innovation performance (Zeng et al., 2015), as well as TQM and hotel labor productivity (Carlos et al., 2014). Meanwhile, some conducted studies by solely incorporating leadership into employee creativity amidst Taiwanese international tourist hotels (Wang et al., 2014) and towards service performance in Taiwanese hotel workplace (Wu et al., 2015).

Despite the important theoretical role of quality management in enhancing business performance and in achieving CA, as previously explained, only a handful of empirical studies have investigated this relationship (see Table 1). In precise, in order to detect research gaps in this research area, a thorough search in some social sciences databases had been performed. Table 1 displays several gaps in the quality management and business performance/CA literature, which represent issues for further investigations. Based on Table 1, first, there is a shortage of studies that link quality management with CA. Second, amongst the studies that had investigated the relationship between quality management and CA, there is absence in studies that assessed this relationship within the hotel industry. In conclusion, the results of searching in the above databases clearly exhibited the existence of research gaps.

\section{Conclusion}

After a thorough TQM review, the literature seems to lack a model that can be considered for choosing suitable TQM elements within the hotel settings. In other words, most of the past studies have identified TQM factors based on other authors' experience or based on historical data, in which some of these criteria are not clearly defined. As suggested in the previous section, other sources are recommended in order to reach an appropriate research methodology and collection of data, which can be adapted to the specific requirements of the study. On behalf of assessing and evaluating TQM within the hotel industry, to date, only one study conducted by Abbas et al., (2015) is available using two fuzzy methods to determine quality management critical success factors (CSFs) in Iranian SME hotels. As such, none of the existing published researches has reviewed the association between TQM and CA via mixed method design, hence leaving a myth for academicians and practitioners. In fact, this presents as a crucial issue that should be addressed in order to identify clear and well-rounded answers on the degree and extension of quality management practices in Malaysia's hotel industry (Wu \& Chen, 2015; Carlos, et al., 2014).

\section{References}

Abbas M., Ahmad J., Mahdi M. B., Mansooreh K. (2015). “A Combined Hybrid Fuzzy Multiple Criteria Decision-making Approach to Evaluating of QM Critical Success Factors in SME's Hotels Firms", Contemporary Issues in Management and Social Science Research, Volume 172, 27 January 2015, Pages 786-793.

Abbas, Q., Hunjra, A., Azam, R., ljaz, M., \& Zahid, M. (2014). Financial performance of banks in Pakistan after Merger and Acquisition. Journal of Global Entrepreneurship Research, 4(1), 1-15. Al-Dhaafri, H. S., Yusoff, R. Z., \& Al-Swidi, A. K. (2013). 'The Effect of Total Quality Management, 
INTERNATIONAL JOURNAL OF ACADEMIC RESEARCH IN BUSINESS AND SOCIAL SCIENCES Vol. 9, No. 5, May, 2019, E-ISSN: 2222-6990 ㄷ 2019 HRMARS

Enterprise Resource Planning and the Entrepreneurial Orientation on the Organizational Performance: The Mediating Role of the Organizational Excellence --- A Proposed Research Framework', International Journal of Business Administration, Vol. 4, No. 1; 2013.

Al-Hawary, S. I. S., \& Abu-Laimon, A. A. A. (2013). The impact of TQM practices on service quality in cellular communication companies in Jordan. International Journal of Productivity and Quality Management, 11(4), 446-474.

Ali, N. A., Mahat, F., \& Zairi, M. (2010). Testing the criticality of HR-TQM factors in the Malaysian higher education context. Total Quality Management \& Business Excellence, 21(11), 1177-1188. doi: $10.1080 / 14783360701349534$.

Andersén, J. (2011). Strategic resources and firm performance. Management Decision, 49(1), 8798.

Ang, Y.-S., Lee, V.-H., Tan, B.-I., \& Chong, A. Y. L. (2011). The impact of TQM practices on learning organisation and customer orientation: a survey of small service organisations in Malaysia. International Journal of Services, Economics and Management, 3(1), 62-77.

Arasli, H. (2012). Towards Business Excellence in the Hospitality Industry: A Case for 3- 4-, and 5-star hotels in Iran. Total Quality Management Journal, 23(5), 573-590

Arawati A., \& Zafaran H. (2011). "Enhancing Production Performance and Customer Performance through Total Quality Management (TQM): Strategies For Competitive Advantage", he Proceedings of 7th International Strategic Management Conference, Volume 24, 2011, Pages 1650-1662.

Baird, K., Hu, K.J. and Reeve, R. (2011), "The relationships between organizational culture, total quality management practices and operational performance", International Journal of Operations and Production Management, Vol. 31 No. 7, pp. 789-814.

Barney, J. B. (1991). Firm Resources and Sustained Competitive Advantage, Journal of Management, $17(1), 99-120$.

Bon, A. T., \& Mustafa, E. M. A. (2013). Impact of Total Quality Management on Innovation in Service Organizations: Literature Review and New Conceptual Framework. Procedia Engineering, 53,516529.

Calvo-Mora, A., Picon, A., Ruiz, C. and Cauzo, L. (2014), "The relationships between soft-hard TQM factors and key business results", International Journal of Operations and Production Management, Vol. 34 No. 1, pp. 115-143.

Carlos, G. B. C., \& Bienvenido, O. (2014). The impact of quality management on productivity in the hospitality sector. International Journal of Hospitality Management, 42, 165-73.

Casanueva, C., Gallego, A., \& Revilla, M. A. (2015). Access and mobilization of network resources and competitive advantage in hotels: a conceptual framework. International Journal of Contemporary Hospitality Management, 27(6), 1-15.

Cemal Z., Oznur G. E., Songul Z., Busra M. (2012). "The Mediating Role of Firm Innovativeness on Management Leadership and Performance Relationship", The First International Conference on Leadership, Technology and Innovation Management, Volume 41, 2012, Pages 29-36.

Changiz, V., \& Shervin R. (2015). The guidelines of improvement: Relations among organizational culture, TQM and performance. International Journal of Production Economics, 164 C), 167-178. 
INTERNATIONAL JOURNAL OF ACADEMIC RESEARCH IN BUSINESS AND SOCIAL SCIENCES Vol. 9, No. 5, May, 2019, E-ISSN: 2222-6990 @ 2019 HRMARS

Chen, F. H., Hsu, T. S., \& Tzeng, G. H. (2011). A balanced scorecard approach to establish a performance evaluation and relationship model for hot spring hotels based on a hybrid MCDM model combining DEMATEL and ANP. International Journal of Hospitality Management, 30(4), 908-932.

Costantini, A., \& Zanin, F. (2015). The influence of total quality management on risk identification and non-financial performance measures: an Italian-based empirical analysis. International Journal of Management Cases, 17(4), 73-78.

Chiarini, A., \& Baccarani, C. (2016). TQM and lean strategy deployment in Italian hospitals: benefits related to patient satisfaction and encountered pitfalls. Leadership in Health Services, 29(4), 377-391.

Coleman, D. A., de Chernatony, L., \& Christodoulides, G. (2015). B2B service brand identity and brand performance. European Journal of Marketing, 49(7/8), 1139-1162.

Debbie M. T., \& Robert, J. B. (2014). International Journal of Contemporary Hospitality Management, 85-106.

Dunes, M., \& Pras, B. (2013). Practices in the brand management system: identification and considerations for five business sectors. Journal of Product \& Brand Management, 22(7), 444461.

Fotopoulos, C., \& Psomas, E. (2010). The structural relationships between TQM factors and organizational performance. The TQM Journal, 22(5), 539-552.

Gallo, A. (2016). A refresher to return on assets or return on equity. Harvard Business Review, available at: https://hbr.org/2016/04/a-refresher-on-return-on-assets-and-return-on-equity

Gambi, L. D. N., Gerolamo, M. C., \& Carpinetti, L.C.R. (2013). A theoretical model of the relationship between organizational culture and quality management techniques. ProcediaSocial and Behavioral Sciences, 81(81), 334-339.

Gholamhossein, M., Jamal, A. N., Hamid, R.R., \& Sajjad, H. (2016). TOPSIS approach to prioritize critical success factors of TQM: Evidence from the pharmaceutical industry. The TQM Journal, 28(2), 235 - 249.

Gholamreza, J., Mehran, E., \& Mohammad, A. A. (2010). "TQM implementation: An investigation of Critical Success Factors", Education and Management Technology (ICEMT), 2010 International Conference, pp. 112 - 116.

Haider, A., Shoaib, M., \& Kanwal, S. (2015). Impact of Mergers on Performance of Banking Sector of Pakistan. Pakistan Business Review, 17(1), 60-79.

Hassan S. A., Rushami Z. F., Abdullah K.A. (2013). The Effect of Total Quality Management, Enterprise Resource Planning and the Entrepreneurial Orientation on the Organizational Performance: The Mediating Role of the Organizational Excellence --- A Proposed Research Framework. International Journal of Business Administration, Vol. 4, No. 1; 2013, pp.66-85.

Hazilah, A. M. N. (2009). Practice follows structure: quality management in Malaysian public hospitals. Measuring Business Excellence, 13(1), 23-33.

Herzallah, A. M., Gutiérrez-Gutiérrez, L., \& Munoz Rosas, J.F. (2014). Total quality management practices, competitive strategies and financial performance: the case of the Palestinian industrial SMEs. Total Quality Management \& Business Excellence, 25(5-6), 635-649. 
INTERNATIONAL JOURNAL OF ACADEMIC RESEARCH IN BUSINESS AND SOCIAL SCIENCES Vol. 9, No. 5, May, 2019, E-ISSN: 2222-6990 @ 2019 HRMARS

Ho, C. T. B., \& Lin, W. C. (2010). Measuring the service quality of internet banking: scale development and validation. European Business Review, 22(1), 5-24.

Horng, J. S., Liu, C. H., Chou, S. F., Yin, Y. S., \& Tsai, C. Y. (2013). Developing a Novel Hybrid Model for Industrial Environment Analysis: A Study of the Gourmet and Tourism Industry in Taiwan. Asia Pacific Journal of Tourism Research(ahead-of-print), 1-26.

Huang, Y. S., Chang, W. C., Li, W. H., \& Lin, Z. L. (2013). Aggregation of utility-based individual preferences for group decision-making. European Journal of Operational Research, 229, 462-469.

Hung, R. Y. Y., Lien, B. Y. H., Yang, B., Wu, C. M., \& Kuo, Y. M. (2011). Impact of TQM and organizational learning on innovation performance in the high-tech industry. Int. Bus. Rev, 20, 213-225.

HVS, October 2015 full report. (hvs.com)

Irfan, S. M., Ijaz, A., Kee, D. M. H., \& Awan, M. (2012). Improving operational performance of public hospital in Pakistan: a TQM-based approach. World Applied Sciences Journal, 1(6), 904913.

Jacobson, R., \& Mizik, N. (2013). The financial markets and customer satisfaction: reexamining possible financial market mispricing of customer satisfaction. Marketing Science, 28(5), 810819.

Jose, F. M. A., Juan, J. T., Jorge, P. M., Maria, D. L. G., \& Eva, M. P. O. (2015). The effects of quality and environmental management on competitive advantage: A mixed methods study in the hotel industry. Tourism Management 50, 41-54.

Juan J. T., Enrique C. C., Jorge P. M., \& Jose F. M. A. (2010). Levels of quality and environmental management in the hotel industry: Their joint influence on firm performance. International Journal of Hospitality Management 29, 500-510.

Junior, M. V., Lucato, W. C., Vanalle, R. M., \& Jagoda, K.(2014). Effective management of international technology transfer projects: Insights from the Brazilian textile industry. Journal of Manufacturing Technology Management, 25(1), 69-99.

Karani, S. R., \& Bichanga, W. O. (2012). Effects of Total Quality Management Implementation on Business Performance in Service Institutions: A Case of Kenya Wildlife Services. International Journal of Research Studies in Management, 1, 59-76.

Karfestani, Z. J., Shomami, M. A., \& Hasanvand, M.M. (2013). Organizational citizenship behavior as an unavoidable necessity for increasing the effectiveness of organizations. International Journal of Contemporary Research in Business, 4(9), 827-850.

Katerina, R., Ida, V., Jakub, S. (2013). "Approaches to Quality Management in Hotel Industry", Acta Universitatis Agriculturae et Silviculturae Mendelianae Brunensis, 2013, LXI, No. 7, pp. 26932699.

Khanam, S., Siddiqui, J. and Talib, F. (2013) 'Role of information technology in total quality management: a literature review', International Journal of Advanced Research in Computer Engineering \&Technology, Vol. 2, No. 8, pp.2433-2445.

Khanam, S, Talib, F. and Siddiqui, J. (2015), "Identification of TQM Enablers and IT Resources for ICT Industry: A Pareto Analysis Approach", International Journal of Information Quality (IJIQ), Vol.4, No.1, pp. 18-41.

Lam, S. Y., Lee, V.H., Ooi, K.B., \& Phusavat, K. (2012). A structural equation model of TQM, market orientation and service quality: Evidence from a developing nation. Managing Service Quality: 
INTERNATIONAL JOURNAL OF ACADEMIC RESEARCH IN BUSINESS AND SOCIAL SCIENCES Vol. 9, No. 5, May, 2019, E-ISSN: 2222-6990 ㄷ 2019 HRMARS

An International Journal, 22(3), 281-309, doi: 10.1108/09604521211230996

Leavengood, S., Anderson, T. R., \& Daim, T. U. (2012). Exploring linkage of quality management to innovation. Total Quality Management \& Business Excellence(ahead-of-print), 1-15.

Lee, H. H., \& Lee, C. Y. (2014), The effects of total quality management and organisational learning on business performance: evidence from Taiwanese insurance industries. Total Quality Management and Business Excellence, 25(9/10), 1072-1087.

Liou, F., \& Gao, Y. (2011). Competitive advantage in the online game industry in Taiwan. Journal of Strategy and Management, 4(2),136-154.

Mahadeo, J. D., \& Durbarry, R. (2008). The level of service quality in the mobile telephony sector: the case of Mauritius. International Journal of Services and Operations Management, 4(6), 730-744.

Mahlendorf, M. D., Rehring, J., Schäffer, U., \& Wyszomirski, E. (2012). Influencing foreign subsidiary decisions through headquarter performance measurement systems. Management Decision, 50(4), 688-717.

Masejane, T. P. (2012). 'Total Quality Management and Organizational Performance in the Maluti-APhofung Municipality in the Free State Province'.

Mehmood, S., Qadeer, F., \& Ahmed, A. (2014). Relationship between TQM dimensions and organizational performance. Pakistan Journal of Commerce and Social Sciences, 8(3), 662-679.

Mehralizadeh, Y., \& Safaeemoghaddam, M. (2010). The applicability of quality management systems and models to higher education in a new perspective. The TQM Journal, 22(2), 175-187.

Mensah, J. O., Copuroglu, G., \& Fening, F. A. (2012). Total quality management in Ghana: critical success factors and model for implementation of a quality revolution. Journal of African Business, 13(2), 123-133.

MIDA-Malaysia, (2015). Malaysia Investment Development Authority Official Website [Online]. (http://www.mida.gov.my/home/), 2015 (accessed 22.06.15).

Mihail, D. M., \& Kloutsiniotis, P. (2016). The effects of high-performance work systems on hospital employees' work-related wellbeing: Evidence from Greece. European Management Journal, 1-15.

Phan, A. C., Abdallah, A. B., \& Matsui, Y. (2011). Quality management practices and competitive performance: Empirical evidence from Japanese manufacturing companies. International Journal of Production Economics, 133(2), 518-529.

Philipp, A. K., \& Jörn-Henrik, T. (2012). International Journal of Production Economics, 496-507.

Richard Y. Y. H., Bella Y. H. L., Baiyin Y., Chi-Min W., \& Yu-Ming K. (2011). Impact of TQM and organizational learning on innovation performance in the high-tech industry. International Business Review, 20(2), 213-225.

Sadikoglu, E., \& Olcay, H. (2014). The effects of total quality management practices on performance and the reasons of and the barriers to TQM practices in Turkey. Advances in Decision Sciences, 24(6), 948-975.

Sadikoglu, E., \& Zehir, C. (2010). Investigating the effects of innovation and employee performance on the relationship between total quality management practices and firm performance: An empirical study of Turkish firms. International Journal of Production Economics, 127, 13-26.

Santouridis, I., \& Trivellas, P. (2010). Investigating the impact of service quality and customer satisfaction on customer loyalty in mobile telephony in Greece. The TQM Journal, 22(3), 330-343. 
INTERNATIONAL JOURNAL OF ACADEMIC RESEARCH IN BUSINESS AND SOCIAL SCIENCES Vol. 9, No. 5, May, 2019, E-ISSN: 2222-6990 @ 2019 HRMARS

Sigalas, C., \& Pekka Economou, V. (2013). Revisiting the concept of competitive advantage: problems and fallacies arising from its conceptualization. Journal of Strategy and Management, 6(1), 61-80.

Sigalas, C., Pekka-Economou, V., \& Georgopoulos, N.B. (2013). Developing a measure of competitive advantage. Journal of Strategy and Management, 6(4), 320-342.

Singh, K., and Ahuja, I. S. (2015) "An evaluation of transfusion of TQM-TPM implementation initiative in an Indian manufacturing industry", Journal of Quality in Maintenance Engineering, Vol. 21 Iss: 2, pp.134 - 153.

Sit, W. Y., Ooi, K. B., Loke, S. P., \& Han, G. T. W. (2011). TQM and service quality: a survey of commercial banking industry in Malaysia. International Journal of Services, Economics and Management, 3(1), 78-91.

Snezana, T. (2015). The Implementation of total quality management in order to improve production performance and enhancing the level of customer satisfaction. Procedia Technology, 19,10161022.

Sushila, D. R., Uma, T. M., Saeed, P. S., \& Vikneswaran, N. (2014). Service Quality and Previous Experience as a Moderator in Determining Tourists' Satisfaction with Rural Tourism Destinations in Malaysia: A Partial Least Squares Approach. Procedia Social and Behavioral Science, 203-211.

Talib, F., Rahman, Z., \& Qureshi, M. N. (2013b). An empirical investigation of relationship between total quality management practices and quality performance in Indian service companies. International Journal of Quality and Reliability Management, 30(3), 280-318.

Talabi. J. (2015). The role of marketing in hotel industry Case (Six successful hotel units in Abuja and Jakobstad).

Tasleem, M., Khan, N., \& Masood, S. A. (2015). Integrated Role of TQM and Technology Management in Organizational Sustainability. International Conference on Industrial Engineering and Operations Management, Dubai, UAE, 2015.

Tseng, M. L. Lin, Y. H., Lim, M. K., \& Teehankee, B. L. (2015). Using a hybrid method to evaluate service innovation in the hotel industry. Applied Soft Computing, 28, 411-421.

Valmohammadi, C. (2011). The impact of TQM implementation on the organizational performance of Iranian manufacturing SMEs. The TQM Journal, 23(5), 496-509.

Van Rossem, A., \& Van Veen, K. (2011). Managers' awareness of fashionable management concepts: an empirical study. European Management Journal, 29(3), 206-216.

Wang, C. H., Chen, K. Y., \& Chen, S. C. (2012). Total quality management, market orientation and hotel performance: the moderating effects of external environmental factors. International Journal of Hospitality Management, 31(1), 119-129.

Wang, C., Tsai, H. T., \& Tsai, M. T. (2014). Linking transformational leadership and employee creativity in the hospitality industry: The influences of creative role identity, creative self-efficacy, and job complexity. Tourism Management, 40(2), 79-89.

Wayhan, V. B., McCallum, M. F., \& Golyer, N. M. (2013). TQM and financial performance: are findings of direct effects methodological artefacts? Total Quality Management and Business Excellence, 24(1\&2), 171-187. 
INTERNATIONAL JOURNAL OF ACADEMIC RESEARCH IN BUSINESS AND SOCIAL SCIENCES

Vol. 9, No. 5, May, 2019, E-ISSN: 2222-6990 @ 2019 HRMARS

World Travel \& Tourism Council (2012). Travel and Tourism Economic Impact 2012. [Online]Available:http://www.wttc.org/site_media/uploads/downloads/world2012.pdf.[14 January 2013]

Wu, C. M., \& Chen, T. J. (2015). Psychological contract fulfillment in the hotel workplace: Empowering leadership, knowledge exchange, and service performance. International Journal of Hospitality Management, 48, 27-38.

Yusoff, W., Aichouni, M., Badawi, I., \& Boujelbene, M. (2016). A survey on the implementation of Total Quality Management (TQM) at manufacturing industries in north region, Kingdom of Saudi Arabia. 2016 2nd International Conference on Information Management (ICIM), London, 84-88.

Zahra, S. K., Alireza, S., \& Mohammad, S. K. (2014). Explanatory study towards analysis the relationship between Total Quality Management and Knowledge Management. 2nd World Conference On Business, Economics And Management, Procedia - Social and Behavioral Sciences, $109,600-604$.

Zeng, J., Anh, P. C., \& Matsui, Y. (2015). Shop-floor communication and process management for quality performance: an empirical analysis of quality management. Management Research Review, 36(5), 454-477.

Zwain, A. A. A., Lim, T. K., \& Othman, N. S. (2017). TQM and academic performance in Iraqi HEls: associations and mediating effect of KM. The TQM Journal, 29(2), 357-368. 